\title{
Quality and Safety Characteristics of Minimally Processed Watermelon (Citrullus lanatus) Sold in Selected Locations in Port Harcourt
}

\author{
Patience C. Obinna-Echem and Loveth Koanyie
}

\begin{abstract}
The physico-chemical, proximate, vitamin C, sensory and microbiological quality of minimally processed watermelon from selected locations in Port Harcourt was evaluated. The locations were Rumuokoro junction, Rumuokuta junction, Nwinpi junction and Mile 3 Bus stop, samples prepared in the Food preparation laboratory served as control. Standard analytical and microbiological methods were used. pH and titratable acidity varied respectively from $4.95-5.60$ and $0.14-0.20 \%$ Citric acid. Moisture, protein, fat, ash, crude fibre, and carbohydrate ranged from $94.54-96.14,0.52-0.54,0.54-$ $0.56,0.25-0.39,0.32-0.57$ and $1.99-3.56 \%$ respectively, while the energy content was $15.00-20.91 \mathrm{Kcal} / \mathrm{g}$. Ascorbic acid content ranged from $2.77-4.73 \mathrm{mg} / 100 \mathrm{~g}$. The microbiological evaluation revealed Total aerobic, Coliform, Escherichia coli, Salmonella, Staphylococcus and fungi counts of 3.80 - 5.79, 3.74 - 5.83, 5.10 - 5.84, 4.26 - 5. 00 and $3.89-4.45 \log _{10} \mathrm{Cfu} / \mathrm{g}$ respectively. The sensory attributes: colour, sweetness, texture, aroma, juiceness and overall acceptability of the samples ranged from $5.80-7.85,5.70-7.95,6.10-7.45,5.40-7.10,6.15-7.55$ and $6.00-7.45$ respectively. Degree of likeness of the minimally processed watermelon by the assessors was that of slight to like very much. The study revealed that though the minimally processed watermelon were nutritious and acceptable to the consumers, the microbial counts were unsatisfactory and can be a risk factor to public health.
\end{abstract}

Index Terms-Ascorbic acid, minimally processed watermelon, proximate composition, sensory and microbiological qualities

\section{INTRODUCTION}

Watermelon (Citrullus lanatus) is a vine-like flowering plant that belong to the family (Cucurbitaceae) originally from southern Africa [1] but now grown in almost all parts of Africa. Citrullus species, are native to Africa and have been cultivated since ancient times [2]. It is a large, sprawling annual plant with coarse, hairy pinnately, lobed leaves and white to yellow flowers. The fruits are large, oval, round or oblong in shape and has a smooth hard rind. The rind can be solid green or dark green with pale green stripes that turn yellowish green when ripe [3]. The pulp is a juicy sweet interior flesh, usually deep red, pink, yellow or orange in colour white with many flat, oval black seeds [4 - 5]. Watermelon are minimally processed by cutting into halves, quarters, sixths or eights and packaged in polyethylene bags or in plastic containers when the rids are removed and cut into small cubes. The minimally processed watermelon can be blended and consumed as juice [6 - 7].

The fruit has both nutritional and medicinal values. The red-fleshed species are rich source of lycopene which is responsible for the fruit flesh colour and other natural antioxidants [8]. The high level of antioxidant helps in decreasing the risk of kidney stone and bone loss due to old age. The lycopene content plays a role in the protection of prostrate and oral cancer [9]. Watermelon contains citrulline, an amino acid that may increase nitric oxide in the body and thus lower blood pressure as nitic oxide helps in the expansion of blood vessels. Watermelon among other fruits contains very high moisture content $(>95 \%)$ and high in protein $(7.7 \%)$. It also contains protein, ash, fibre and carbohydrate, and a good source of ascorbic, citric acid and minerals [10]. The high water content of watermelon makes it a refreshing fruit and perhaps a contributory factor to its name. Consumers are specially interested in food sources rich in antioxidant vitamins (vitamins $\mathrm{C}, \mathrm{A}$, and $\mathrm{E}$ ), minerals (calcium, magnesium, and potassium) [11], hence the increased interest in the consumption of watermelon.

Minimally processed watermelon on display for sale may show some signs of deterioration such as loss of colour and texture, sweetness and juice leakage. Microbiological contamination may not be as visible as those of the sensory attributes except with some visible manifestation of microbial spoilage. Some studies have isolated both microbiological indicators of quality and safety and fungi from watermelon. Some of these microorganisms include Salmonella spp, Bacillus subtilis, Staphylococcus aureus, Proteus spp, Enterobacter spp, Saccharomyces cerevisiae, Mucor sp, Penicillium spp, Aspergillus niger [12 - 14]. The manner of processing involving little or no washing, cutting and packaging in polyethylene bags in the busy roadside or streets where the minimally processed fruits are displayed on trays for sale and the lack of proper personal hygiene practices of the vendor can lead to contamination of the minimally processed watermelon. This raises a concern for public health as potential pathogens can be transmitted via the consumption of such fruits. Consumption of fresh-cut watermelon has been associated with food-borne disease due to the presence of pathogens $[15,16]$. Hence the objective of this study to evaluate the physicochemical, proximate, ascorbic acid, sensory and microbiological quality and safety of minimally

Published on June 19, 2020.

Patience C. Obinna-Echem, Rivers State University, Nigeria.

(e-mail: chisanupat@yahoo.com)

Loveth Koanyie, Rivers State University, Nigeria

(e-mail: lovethkoanyie @yahoo.com) 
processed watermelon sold in selected locations in Port Harcourt Metropolis.

\section{MATERIALS AND METHOD}

\section{A. Sample Collection and preparation}

Samples of minimally processed watermelon (red-fleshed) packaged in transparent polyethylene bags were purchased from four different locations in Port Harcourt. Them samples were coded according to location as: A - Nwinpi junction; B - Rumuokuta junction; C - Rumuokoro junction and D - Mile 3 Bus stop. For the control, watermelon fruit was bought from fruit garden in Port Harcourt. The fruit was washed with distilled water, cut into 6 parts mimicking the sizes sold by street vendors. The fruits pulp was separated from the rind with a clean sharp kitchen knife, chopped into cubes and stored frozen for further analysis. Samples for sensory analysis were cut into smaller sections and served with the rinds which served as the hold.

\section{B. Determination of $\mathrm{pH}$ and Titratable acidity (TTA)}

$\mathrm{pH}$ and Titratable acidity (TTA) as \% Citric acid was determined according to the standard AOAC [17] methods. Briefly, a digital pH meter (pHs-2f Harris, England) was used to determine the $\mathrm{pH}$ of $10 \mathrm{ml}$ of the homogenized and filtered sample in a beaker. Thereafter, the sample was titrated with a solution of $0.1 \mathrm{~N}$ sodium hydroxide using $0.3 \mathrm{ml}$ phenolphthalein as indicator.

\section{Proximate analysis}

The proximate composition of the samples was analyzed according AOAC method [17]. Briefly, moisture was determined by drying the samples in a hot air oven (DHG $9140 \mathrm{~A}$ ) at $130^{\circ} \mathrm{C}$ until a constant weight was obtained. Kjeldahl method was used for crude protein determination and a nitrogen conversion factor of 6.25 was used. The lipid content was determined by soxhlet extraction method with ethyl ether. The ash content was determined gravimetrically after the incineration of the samples in a muffle Furnace (Model SXL) at $550^{\circ} \mathrm{C}$ for 2 hours. Crude fibre was determined using Chemical solubilisation and gravimetric method. The carbohydrate was calculated by difference $\{100$ - (Crude protein + crude fibre + ash + fat $)\}$. Energy values were obtained using Atwater factor of $4 \mathrm{Kcal} / \mathrm{g}$ for protein and carbohydrate and $9 \mathrm{Kcal} / \mathrm{g}$ for fat.

\section{Ascorbic acid determination}

The 2,6-Dichlorophenolindophenol titrimetric method described by James, [18] with some modifications was used in the determination of ascorbic acid content of the samples. Briefly, $0.5 \mathrm{~g}$ of the sample was mixed with $5 \mathrm{ml}$ of metaphosphoric-acetic mixture, homogenized in a blender for $1 \mathrm{~min}$ and then centrifuged at $4000 \mathrm{~g}$ for $10 \mathrm{~min}$. This was repeated twice and the supernatant were mixed together. The metaphosphoric-acetic extract was titrated with 2,6Dichlorophenolindophenol solution until a faint pink colour persists for $15 \mathrm{~s}$.

\section{E. Sensory evaluation}

Sensory analysis was carried out according to the method described by Iwe [19]. The aroma, appearance, colour, flavour, texture/smoothness and overall acceptability of the fruits were assessed by twenty (20) untrained panelist from the university community who often buy and consume minimally processed watermelon. The rating of the attributes was based on a 9 - point hedonic scale with the degree of likeness expressed as: $1=$ disliked extremely, 2 - dislike very much, 3 - dislike moderately, 4 - dislike slightly, 5 - neither like nor dislike, 6 - like slightly, 7 - like moderately, 8 - like very much and 9 - like extremely.

\section{F. Microbiological analysis}

The enumeration of the microbiological quality and safety of the minimally processed watermelon was carried out by conventional method [20]. A serial dilution of $10^{6}$ was prepared from the stock made of $25 \mathrm{~g}$ of the fruit sample homogenized in $225 \mathrm{ml}$ of sterile peptone water. Aliquot $(0.1$ $\mathrm{ml}$ ) of the dilutions were spread plated on appropriate media for each microorganism. Nutrient Agar (NA), Eosin Methylene Blue (EMB), Salmonella-Shegilla Agar (SSA) and Mannitol Salt Agar (MSA) incubated at $37^{\circ} \mathrm{C}$ for $24-48$ $\mathrm{h}$, was respectively, used for the enumeration of Aerobic count, Escherichia coli, Salmonella and Staphylococcus aureus. Coliform was enumerated on MacConkey Agar (MCA) incubated at $30^{\circ} \mathrm{C}$ for $24-48 \mathrm{~h}$. Potato Dextrose Agar (PDA) incubated at $25^{\circ} \mathrm{C}$ for $72 \mathrm{~h}$ was used for mould and yeast enumeration.

\section{RESULTS AND DISCUSSION}

\section{A. Physicochemical Properties of minimally processed watermelon from different location in Port Harcourt}

The $\mathrm{pH}$ and total titratable acidity of minimally processed watermelon from different location in Port Harcourt are shown in Fig. 1.

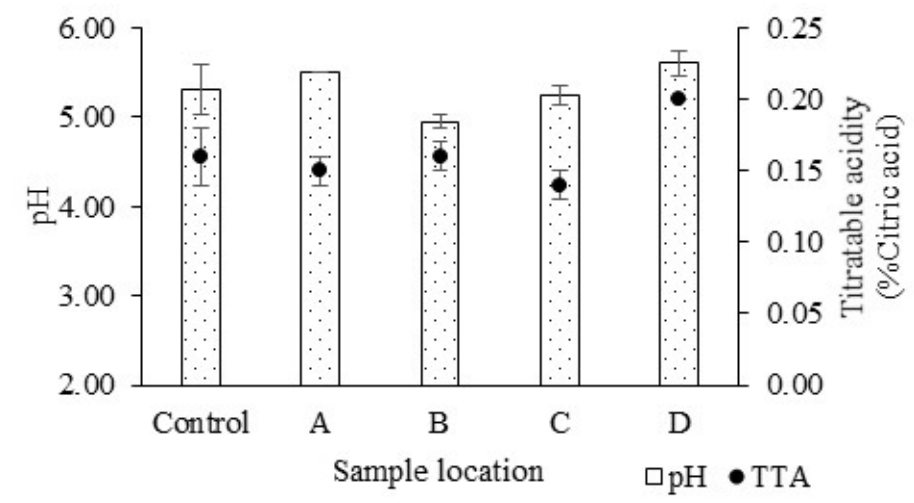

Fig. 1. $\mathrm{pH}$ and Titratble acidity (\%Citric acid) of minimally processed watermelon from selected locations in Port Harcourt Metropolis

A, B, C and D represent samples from Nwinpi, Rumuokuta, Rumuokoro, and Mile 3 Junctions respectively.

There was no significant $(\mathrm{P} \leq 0.05)$ difference among the watermelon samples from the different locations. The $\mathrm{pH}$ of the watermelon varied from $4.95-5.60$ for location B and D respectively. The titrable acidity ranged from $0.14-0.20$ $\%$ Citric acid for location $\mathrm{C}$ and $\mathrm{D}$ respectively. The $\mathrm{pH}$ of the watermelon is similar to other reports [8] even with the pomace of watermelon ( $\mathrm{pH}$ of $5.09-5.20$ ) reported by Arocho et al., [21]. The acidity showed that watermelon contains citric acid. Citric and malic acid have been reported as the main organic acids in watermelon flesh [22]. Citric acid from fruits are important in the alkalization of the body as dietary citrate are absorbed in the intestine and nearly completely metabolized to bicarbonate, which in turn increases urinary $\mathrm{pH}$ [23]. 
TABLE 1. PROXIMATE COMPOSITION (\%) AND ENERGY CONTENT OF MINIMALLY PROCESSED PINEAPPLE, PAWPAW AND WATERMELON FROM DIFFERENT LOCATIONS IN PORT HARCOURT METROPOLIS

\begin{tabular}{|c|c|c|c|c|c|c|c|c|}
\hline Location & Moisture & Total solid & Protein* & Fat & Ash & Fibre & Carbohydrate & Energy (KJ/g) \\
\hline Control & $95.39 \pm 0.44$ & $4.61 \pm 0.44$ & $0.52 \pm 0.01$ & $0.54 \pm 0.00$ & $0.39 \pm 0.04$ & $0.37 \pm 0.07^{\mathrm{a}}$ & $2.97 \pm 0.02$ & $18.77 \pm 3.29$ \\
\hline $\mathbf{A}$ & $96.14 \pm 0.06^{\mathrm{a}}$ & $3.86 \pm 0.06^{\mathrm{a}}$ & $0.52 \pm 0.00$ & $0.55 \pm 0.02$ & $0.33 \pm 0.01$ & $0.32 \pm 0.14^{\mathrm{b}}$ & $1.99 \pm 0.02^{\mathrm{a}}$ & $15.00 \pm 012^{\mathrm{a}}$ \\
\hline B & $94.72 \pm 0.17$ & $5.28 \pm 0.17$ & $0.52 \pm 0.02$ & $0.54 \pm 0.01$ & $0.25 \pm 001^{\mathrm{a}}$ & $0.57 \pm 0.26$ & $3.48 \pm 0.00$ & $20.91 \pm 0.11$ \\
\hline C & $94.54 \pm 0.11$ & $5.46 \pm 0.11$ & $0.52 \pm 0.01$ & $0.55 \pm 0.01$ & $0.39 \pm 0.01$ & $0.54 \pm 0.05$ & $3.56 \pm 0.32$ & $21.91 \pm 1.17$ \\
\hline D & $94.98 \pm 0.04$ & $5.02 \pm 0.04$ & $0.52 \pm 0.01$ & $0.56 \pm 0.03$ & $0.31 \pm 0.05$ & $0.43 \pm 0.04^{\mathrm{a}}$ & $3.20 \pm 0.10$ & $19.89 \pm 0.65$ \\
\hline
\end{tabular}

Means without superscript in the same column for each sample do not differ significantly $(\mathrm{P} \leq 0.05)$. $\mathrm{N}=2 \pm \mathrm{SD}$

A, B, C and D represented samples from Nwinpi, Rumuokuta, Rumuokoro, and Mile 3 Junctions respectively

\section{B. Proximate Composition of Minimally Processed watermelon from Different Location in Port Harcourt.}

The proximate composition and energy content of the minimally processed watermelon are shown in Table 1 . The moisture content of the minimally processed watermelon varied from $94.54-96.14 \%$ for samples from Location c and A respectively.

Moisture content of any food represents the amount of water present in the food and an index of its water activity. It determines the stability and susceptibility of the food to deterioration as water is required for all biochemical reactions and microbial growth. The watermelon samples contained high moisture content $(>94 \%)$ and it is in agreement with other reports $[8,10]$. The high moisture content account for the thirst quenching and perishability of the fruits. The watermelon had a total solid content of $3.86-5.46 \%$, this is a function of the water content of the fruits.

The watermelon samples from the different locations had a protein content of $0.52 \%$. This is similar to the value reported by [8]. Proteins are essential component of diets needed for biological functions and cell structure, foods of animal origins and legumes are the known excellent sources of protein [24], hence the low protein content of the watermelon which is a fruit is not misnomer.

The fat content of $0.54-0.56 \%$ was higher than values reported by Olayinka and Etejere [8] but lower than the report of Bala and Bashar [10]. Fruits generally are not rich sources of protein and fat except for the seed of some.

The carbohydrate content of the samples varied from 1.99 $-3.56 \%$ for location $\mathrm{A}$ and $\mathrm{C}$ respectively. This value was lower than the report by [25]. The low carbohydrate content is attributable to the high moisture content of the watermelon. The low carbohydrate content plays significant role in loss of weight and is ideal for weight watchers.

The ash $(0.25-0.39 \%)$ and fibre $(0.32-0.57 \%)$ content of the watermelon samples was comparable to the report of Olayinka and Etejere [8] but lower than those of Ekpete et al. [25]. Ash is the inorganic residue after the incineration or complete oxidation of organic matter in the food and a representation of the total mineral content in food [26]. Fibre is not absorbable by the body but aids in bowl movement. The watermelon is also a source of energy with contents ranging from $15.00-21.91 \mathrm{Kcal} / \mathrm{g}$.

C. Ascorbic acid content of minimally processed watermelon from selected Locations in Port-Harcourt
Presented in Fig. 2, is the ascorbic acid content of minimally processed watermelon from selected locations in Port Harcourt. It varied from $2.77 \mathrm{mg} / 100 \mathrm{~g}$ for the control to $4.73 \mathrm{mg} / 100 \mathrm{~g}$ for samples from location $\mathrm{D}$. These values were lower than values of $5.5 \mathrm{mg} / 100 \mathrm{~g}$ reported by Tee [27] but similar to the report of $4.08 \mathrm{mg} / 100 \mathrm{~g}$ reported by Nweze et al., [5] for watermelon juice. A serving of $100 \mathrm{~g}$ of the minimally processed watermelon will meet $3.08-6.31 \%$ of the Recommended Dietary Intakes of 75 - $90 \mathrm{mg} /$ day for adult male and female between the ages of $19-50$ years [28]. Ascorbic acid is a relevant antioxidant and immune booster against infections in the body even coronavirus along with medicines when indicated [29]. It also targets many mechanisms that cancer cell utilizes for growth and survival [30].

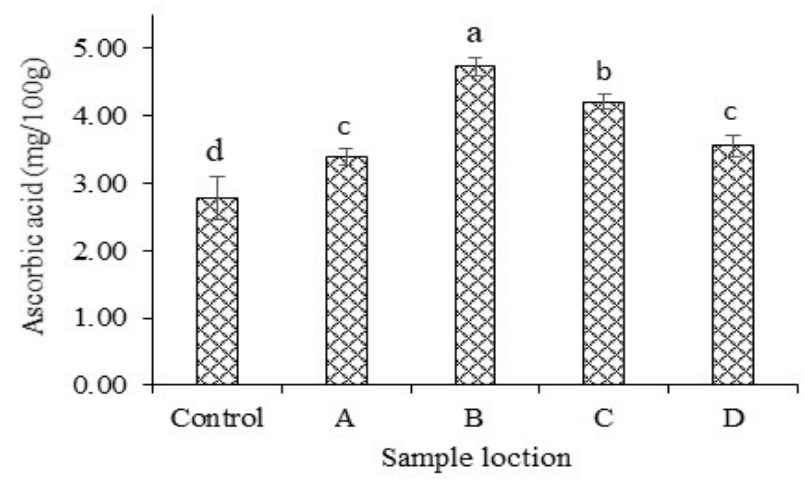

Fig. 2. Ascorbic acid content of minimally processed watermelon from selected Locations in Port-Harcourt

A, B, C and D represent samples from Nwinpi, Rumuokuta, Rumuokoro, and Mile 3 Junctions respectively.

D. Sensory evaluation on minimally processed watermelon from different location in Port Harcourt

The degree of assessor's likeness of the sensory attributes of the minimally processed watermelon from the selected locations is shown in Table 3. There were significant variations among samples. The colour, sweetness, texture, aroma, juiceness and overall acceptability of the samples ranged from $5.80-7.85,5.70-7.95,6.10-7.45,5.40-7.10$, $6.15-7.55$ and $6.00-7.45$ respectively. The colour of samples from location $\mathrm{D}$ was the significantly $(\mathrm{P} \leq 0.05)$ the least liked by the assessors while the significantly $(\mathrm{P} \leq 0.05)$ least liked of the other attributes was samples from location C. The assessors' liked the minimally processed watermelon 
regardless of location and the degree of likeness was from slightly to like very much. was that of slight to very much liked.

TABLE 2. SENSORY EVALUATION ON MINIMALLY PROCESSED WATERMELON FROM SELECTED LOCATIONS IN PORT HARCOURT

\begin{tabular}{lllllll}
\hline \hline Location & $\begin{array}{l}\text { Appearance/ } \\
\text { Colour }\end{array}$ & Sweetness & Texture & Aroma & Juiciness & Overall Acceptability \\
\hline Control & $7.85 \pm 0.99^{\mathrm{a}}$ & $7.60 \pm 1.05^{\mathrm{a}}$ & $7.30 \pm 1.26^{\mathrm{a}}$ & $6.75 \pm 2.17^{\mathrm{a}}$ & $7.45 \pm 1.40^{\mathrm{a}}$ & $7.45 \pm 0.89^{\mathrm{a}}$ \\
$\mathbf{A}$ & $7.25 \pm 1.12^{\mathrm{b}}$ & $7.95 \pm 0.94^{\mathrm{a}}$ & $7.45 \pm 1.40^{\mathrm{a}}$ & $7.05 \pm 1.91^{\mathrm{a}}$ & $7.15 \pm 1.18^{\mathrm{a}}$ & $7.45 \pm 0.89^{\mathrm{a}}$ \\
B & $7.45 \pm 0.95^{\mathrm{ab}}$ & $7.80 \pm 1.06^{\mathrm{a}}$ & $7.25 \pm 1.33^{\mathrm{a}}$ & $7.10 \pm 1.86^{\mathrm{a}}$ & $7.55 \pm 1.28^{\mathrm{a}}$ & $7.50 \pm 0.95^{\mathrm{a}}$ \\
C & $6.80 \pm 1.54^{\mathrm{b}}$ & $5.70^{\mathrm{a}} \pm 1.87^{\mathrm{b}}$ & $6.10 \pm 2.15^{\mathrm{b}}$ & $5.40 \pm 2.26^{\mathrm{b}}$ & $6.15 \pm 2.06^{\mathrm{b}}$ & $6.00^{\mathrm{a}} \pm 1.81^{\mathrm{b}}$ \\
D & $5.80 \pm 1.67^{\mathrm{c}}$ & $6.15 \pm 1.57^{\mathrm{b}}$ & $6.25 \pm 1.65^{\mathrm{b}}$ & $5.60 \pm 1.64^{\mathrm{b}}$ & $6.45 \pm 1.99^{\mathrm{b}}$ & $6.25 \pm 14.81^{\mathrm{b}}$ \\
\hline \hline
\end{tabular}

Means with the same superscript in the same column differ significantly $(\mathrm{P} \leq 0.05) . \mathrm{N}=20 \pm \mathrm{SD}$

A, B, C and D represented samples from Nwinpi, Rumuokuta, Rumuokoro, and Mile 3 Junctions respectively
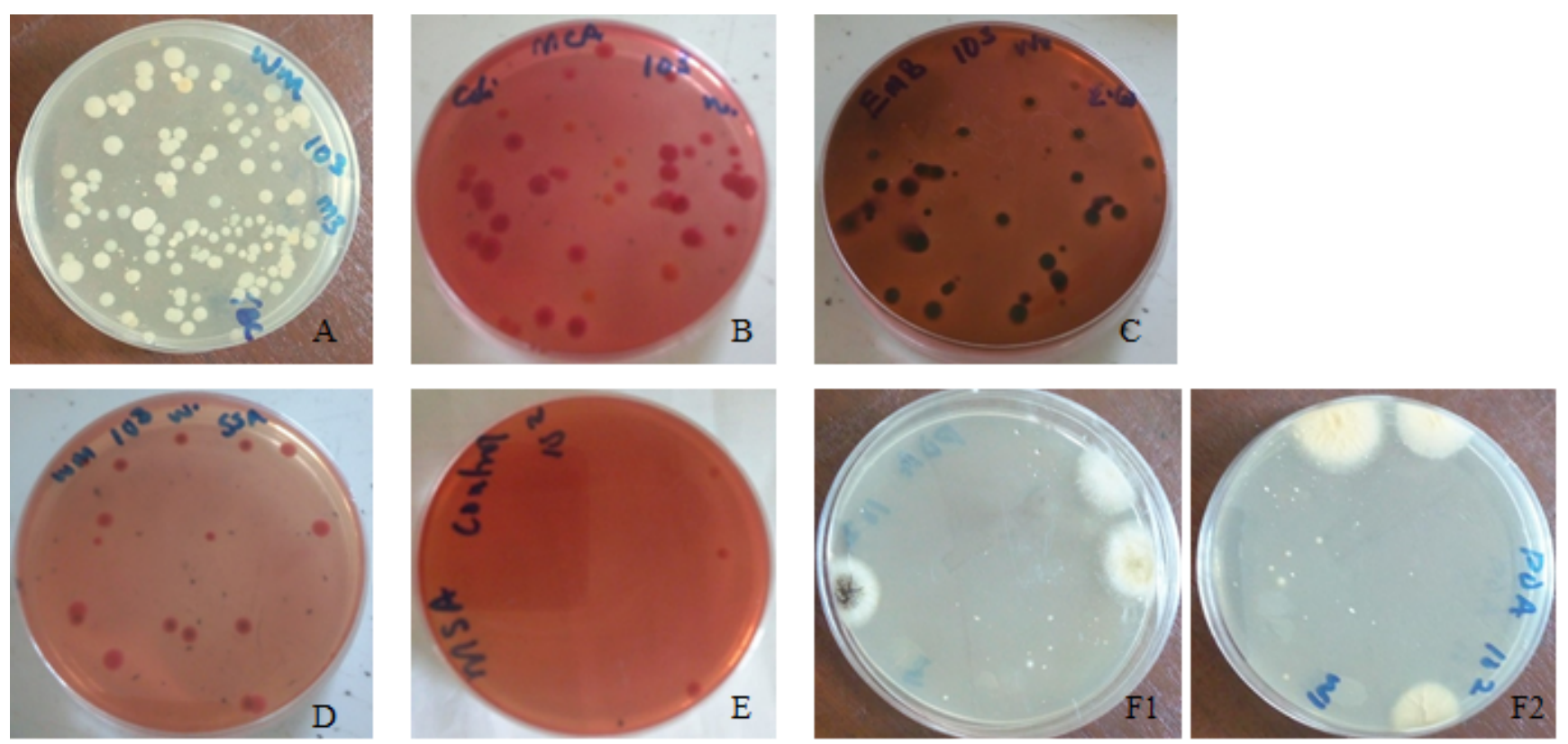

Fig. 3. Some images of plate cultures showing culture morphology of the enumerated microorganisms.

A - Total aerobic count on Nutrient Agar (NA). White circular colonies of different sizes

$\mathrm{B}$ - Coliform on MacConkey Agar (MCA) incubated at $30^{\circ} \mathrm{C}$ for $24-48 \mathrm{~h}$

$\mathrm{C}$ - Eshcherishia coli on Eosin Methylene Blue (EMB), incubated at $37^{\circ} \mathrm{C}$ for $24-48$

D - Salmonella on Salmonella-Shegilla Agar (SSA) incubated at $37^{\circ} \mathrm{C}$ for $24-48$

E - Staphylococcus on Mannitol Salt Agar (MSA) incubated at $37^{\circ} \mathrm{C}$ for $24-48$

F1 \& F2 - Top and back of Fungi on Potato Dextrose Agar (PDA) incubated at $25^{\circ} \mathrm{C}$ for $72 \mathrm{~h}$

TABLE 3 MICROBIOLOGICAL QUALITY (LOG 10 CFU/G) OF MINIMALLY PROCESSED WATERMELON FROM SELECTED LOCATIONS IN PORT HARCOURT

\begin{tabular}{|c|c|c|c|c|c|c|}
\hline Location & Total aerobes & Total Coliform & E.coli & Salmonella & Staphylococcus aureus & Fungi \\
\hline Control & $4.30 \pm 0.99^{\mathrm{ab}}$ & $2.48 \pm 0.16^{\mathrm{b}}$ & NG & NG & $2.48 \pm 0.01^{\mathrm{b}}$ & NG \\
\hline $\mathbf{A}$ & $5.41 \pm 0.47^{\mathrm{ab}}$ & $5.41 \pm 0.32^{\mathrm{a}}$ & $5.10 \pm 0.54^{\mathrm{a}}$ & $5.10 \pm 0.19^{b}$ & $4.26 \pm 0.31^{\mathrm{a}}$ & $4.09 \pm 0.55^{\mathrm{a}}$ \\
\hline B & $5.79 \pm 0.51^{\mathrm{a}}$ & $5.83 \pm 0.49^{\mathrm{a}}$ & $5.48 \pm 026^{\mathrm{a}}$ & $5.84 \pm 0.01^{\mathrm{a}}$ & $4.39 \pm 0.55^{\mathrm{a}}$ & $3.89 \pm 0.16^{\mathrm{a}}$ \\
\hline $\mathbf{C}$ & $3.80 \pm 0.71^{\mathrm{b}}$ & $3.74 \pm 0.37^{b}$ & $4.07 \pm 0.32^{\mathrm{b}}$ & NG & NG & $4.45 \pm 0.23^{\mathrm{a}}$ \\
\hline D & $5.72 \pm 0.56^{\mathrm{a}}$ & $5.62 \pm 0.37^{\mathrm{a}}$ & $5.61 \pm 0.36^{\mathrm{a}}$ & $5.48 \pm 0.17^{\mathrm{a}}$ & $5.00 \pm 0.41^{\mathrm{a}}$ & $4.00 \pm 0.00^{\mathrm{a}}$ \\
\hline
\end{tabular}

Means with the same superscript in the same column do not differ significantly $(\mathrm{P} \leq 0.05) . \mathrm{N}=3 \pm \mathrm{SD}$

NG - No growth

A, B, C and D represented samples from Nwinpi, Rumuokuta, Rumuokoro, and Mile 3 Junctions respectively 


\section{E. Microbiological quality and safety of minimally processed watermelon from selected location in Port Harcourt}

The microbiological quality of the minimally processed watermelon from selected locations in Port Harcourt are shown in Table 3. The enumerated microorganisms are: Total Aerobes, Coliform, Escherishia coli, Salmonella, Staphylococcus aureus and fungi. Some plate cultures of the enumerated microorganisms are shown in Fig. 3. The aerobic bacteria on the nutrient agar were of different sizes, shapes, and colour predominantly white to cream. Coliform can ferment lactose and appeared as pink cloudy colonies on MacConkey Agar. On Eosin Methylene Blue (EMB), Eshcherishia coli appeared as dark colonies with greenish colouration around the colony. Salmonella on SalmonellaShegilla Agar (SSA) were seen as pink colonies, some with black center. Staphylococcus aureus ferments mannitol to produce a strong acid that changes phenol red to yellow [31]. This was not the case with the control sample hence it was concluded that there was no Staphylococcus aureus in the control sample. What was seen could be of other noncoagulase species that do not ferment mannitol [32]. The moulds on the Potato Dextrose Agar (PDA) were filamentous with black colour on the top but cream at the bottom, which is typical of Aspergilus [33, 34]. The presences of these microorganisms in watermelon have also been established by other authors $[12,13]$. In the Control sample, Coliform was below detection limit and there was no growth of E. coli, Salmonella, Staphylococcus and fungi. Samples from location D had no growth of Salmonella and Staphylococcus. The total aerobic count varied from $3.80-5.79 \log _{10} \mathrm{Cfu} / \mathrm{g}$ with location $\mathrm{D}$ recording significantly $(\mathrm{P} \leq 0.05)$ the least count. Total aerobic count is an indicator of quality not safety and may not be a priority in risk assessment of fruits. There is no applicable level of total aerobes in the guideline for interpretation of result for fruits and vegetables, it can provide useful information about the general quality and shelf-life of the fruits [35].

Coliform was below detection limit in the control sample and varied from $3.74-5.83 \log _{10} \mathrm{Cfu} / \mathrm{g}$ in samples from the selected locations. This level of Total coliform in the minimally processed watermelon exceeded the maximum permitted levels of $2 \log _{10} \mathrm{CFU} / \mathrm{ml}(100 \mathrm{CFU} / \mathrm{ml})$ in fresh produce [35]. The presence of high coliform in food indicate inadequate processing, cross-contamination with raw materials and dirty utensils as well as improper storage temperature which can lead to the multiplication of pathogenic and toxigenic organism though coliforms are nonpathogenic [36].

The presence of $E$. coli in the minimally processed watermelon indicates direct or indirect feacel contamination and poor hygiene practice by vendors as $E$. coli is a natural component of human gut flora. There was no growth of $E$. coli in the control sample. The levels of $4.07-5.61$ $\log _{10} \mathrm{Cfu} / \mathrm{g}$ in the watermelon samples from the different locations were unsatisfactory, exceeding the guideline of $<2$ $\log _{10} \mathrm{CFU} / \mathrm{g}$ [35]. Though it is generally an indicator of hygiene, it can pose food safety problems as some are enterotoxigenic [37].

Salmonella is an indicator of safety, its presence in readyto-eat food is a risk factor as the guideline states that there should be absence of it in $25 \mathrm{~g}$ of sample. The minimally processed watermelon from the different locations had counts of $5.10-5.84 \log _{10} \mathrm{Cfu} / \mathrm{g}$ and by the guideline, they are unsafe for human consumption except for the control and samples from location D. Eni [12] also established the presence of Salmonella in watermelon from Sango, Ota, Nigeria. Presence of salmonella is an indication of cross contamination associated with poor hygiene especially dirty roadside locations [38].

The level of Staphylococcus aureus (4.26 - 5. 00 $\log _{10} \mathrm{Cfu} / \mathrm{g}$ ) in the minimally processed watermelon are unsatisfactory as levels $\geq 4 \log _{10} \mathrm{CFU} / \mathrm{g}\left(10^{4} \mathrm{CFU} / \mathrm{g}\right)$ are considered potentially hazardous. Foods with this level of contamination may cause food poisoning if consumed. The presence of Staphylococcus aureus in the minimally processed watermelon indicates excessive handling and time/temperature abuse [39].

In the minimally processed watermelon, the level of yeast and moulds varied from $3.89-4.45 \log _{10} \mathrm{CFU} / \mathrm{g}$. Some yeast and moulds are significant spoilage microorganisms and the high moisture content and low $\mathrm{pH}$ of fruits gives yeasts and moulds advantage over many bacteria [40]. The levels of yeast in the watermelon from the four selected locations were higher than $2.48-2.86 \log _{10} \mathrm{CFU} / \mathrm{g}\left(3.0 \times 10^{2}-7.0 \times 10^{2}\right.$ $\mathrm{CFU} / \mathrm{g}$ ) reported in ready-to-eat watermelon from Ogun State by [13] but lower than those of $5.28-5.74 \log _{10} \mathrm{CFU} / \mathrm{g}$ $\left(1.9 \times 10^{5}-5.5 \times 10^{5} \mathrm{CFU} / \mathrm{g}\right)$ reported in sliced watermelon in Umuahia [14]. The contamination with fungi could be attributed to personal hygiene and the environment as most fungi are airborne. Important fungi isolated from watermelon include Rhizopus sp, Mucor sp, Saccharomyces cerevisiae, Penicillium spp, Aspergillus niger [14]. Saccharomyces cerevisiae is fermentative, Rhizopus, Mucor and Penicillium are associated with spoilage while the presence of Aspergallus may be hazardous to public health as they are known producers of aflatoxins [13, 38].

The microbial load of the minimally processed watermelon from the selected locations were high and exceeded the recommended satisfactory levels. The high microbial load in addition to the natural microflora can be attributed to factors such as contaminated soil, irrigation water, environment during storage and transportation, poor hygiene, use of contaminated washing/rinsing water during processing, the use of dirty processing utensils, the environment of display at point of sales [41]. The manner of preparation of the minimally processed watermelon can encourage contamination especially the long period of exposure before packaging. The watermelon is usually cut using sharp kitchen knives with bare hands. They are left uncovered in the open environment during packaging, after which they are displayed on tables in the harsh weather conditions. Amusan et al. [42] recommended the use of latex gloves to minimize excessive human hand contact. Minimally processed fruits are not heat processed, they are to be handled and stored at refrigeration temperature $\left(<5^{\circ} \mathrm{C}\right)$ in order to achieve microbiological safety and shelf life [43]. Temperature can be check according to Eni [12], by the use of cool temperature controlled carts similar to those used by vendors of yoghurts and ice creams. It will also be helpful for the vendors to be sensitized on the importance of personal hygiene and proper sanitary ways of processing fruits to reduce contamination.

\section{ACKNOWLEDGEMENTS}

The authors appreciate the technical assistance of Ernest Gbibari and Friday Owuno of the microbiological and 
analytical unit of the Food Science and Technology Laboratory, Rivers State University, Port Harcourt, Nigeria.

\section{REFERENCES}

[1] M. M. Hoque and A. Iqbal. Drying of Watermelon Rind and Development of Cakes from Rind Powder. International Journal of Novel Research in Life Sciences, vol. 2, no. 1, pp. 14-21, January - February 2015.

[2] H.S. Paris. Origin and emergence of the sweet dessert watermelon, Citrullus lanatus. Annals of Botany, vol. 116, pp. 133-148, 2015. doi:10.1093/aob/mcv077, available online at www.aob.oxfordjournals.org

[3] A. Koocheki, S. M. A. Razavi, E. Milani, T. M. Morighadam, M. Abedini, S. Alamatiyan and S. Izadkhah. Physical properties of watermelon seed as a function of moisture content and variety, International Argophysics, vol. 21, pp. 349-359, 2007

[4] P. W. Addo, J. K. Agbenorhevi and D. Adu-Poku. Antinutrient contents of watermelon seeds, MOJ Food processing and Technology, vol. 6, no. 2, pp. 237-239, 2018

[5] C.C. Nweze, M.G. Abdulganiyu and O.G. Erhabor, Comparative analysis of vitamin $\mathrm{C}$ in fresh fruits juice of Malus domestica, Citrus sinensi, Ananas comosus AND Citrullus lanatus by iodometric titration, International Journal of Science, Environment and Technology, vol. 4, no. 1, pp. 17-22, 2015.

[6] F. I. Onyeleke, A. M. Olaniyan and K. Z. Ahmed, Extraction of juice from some tropical fruits using a small scale multi fruit juice extractor. $8^{\text {th }}$ African Crop Science Society Conferene, El-Minia, pp. 1083 - 1808, Egypt, 27-31 October 2007.

[7] G. Oms-Olin, I. Odriozola - Serrano, R. Soliva - Fortuny, O. Martin - Belloso. Effects of high - intensity pulsed electric fixed processing condition on lycopene, Vitamin $\mathrm{C}$ and antioxidant capacity of watermelon juice, Food chemistry, vol. 115, pp. 1312 $-1319,2009$

[8] B.U. Olayinka and E.O. Etejere, Proximate and chemical composition of watermelon (Citrullus lanatus (Thunb.) Maisum and Nakai cv red and cucumber (Cucumis sativus L. cv Pipino) International Food Research Journal, vol. 25, no. 3, pp. 1060 1066, 2018.

[9] A. M. Gwana, M. M. Bako, B. Y. Bagudu, A. B. Sadiq, and M. M. Abdullahi, Determinations of phytochemical, vitamin, mineral and proximate compositions of varieties of watermelon seeds cultivated in Borno State, North-Eastern Nigeria. International Journal of Nutrition and Food Science, vol. 3, no. 4, pp. 238-245, 2014

[10] M. Bala and J. B. Bashar, Proximate and mineral elements composition of five locally consumed fruits in Kano State, Nigeria. Bayero Journal of Pure and Applied Sciences, vol. 10, no. $2,172-176$

[11] M. M. Wall, Ascorbic acid, vitamin A, and mineral composition of banana (Musa sp.) and papaya (Carica papaya) cultivars grown in Hawaii. Journal of Food Composition and Analysis, vol. 19, pp. 434-445, 2006.

[12] A. O. Eni, I. A. Oluwawemitan and O. U. Solomon, Microbial quality of fruits and vegetables sold in Sango Ota, Nigeria, African Journal of Food Science, vol. 4, no. 5, pp. 291- 296, May 2010.

[13] S. Oranusi and O. J. Owrunfemi "Microbiological safety evaluation of street vended ready-to-eat fruits sold in Ota, International Journal of Research in Biological Sciences, vol. 1, no. 3, pp. 22-26, 2011.

[14] E. Nwachukwu and H.U. Osuocha, Microbiological assessment of ready-to-eat sliced Pawpaw (Carica papaya) and Watermelon (Citrullus lanatus) vended in Umuahia, Nigeria. International Journal of Current Microbiology and Applied Science, vol. 3, no. 6, pp. 910-916, 2014.

[15] K. A. Walsh, S.D. Bennett, M. Mahovic and L. H. Gould, Outbreaks Associated with Cantaloupe, Watermelon, and Honeydew in the United States, 1973-2011. Foodborne Pathogens and Disease, vol. 11, no. 12, pp. 945-952, December 2014. doi:10.1089/fpd.2014.1812

[16] G. M. Heard, Microbiology of fresh-cut produce. In: O. Lamikanra (ed.) Fresh-Cut Fruits and Vegetables. Science, Technology, and Market. CRC press, Boca Raton, FL. 2002.
[17] AOAC, Official Method of Analysis Associate of Analytical chemists, $19^{\text {th }}$ Edition, Washington DC, 2012, pp. $121-130$

[18] C. S. James, Analytical chemistry of Foods, Aspen Publishers, INC. Gaitherburg, Maryland. 1999, pp. 137 -138.

[19] M.O. Iwe, Handbook of sensory methods and analysis, Rojoint communication services. Enugu. 2002, pp. $71-72$.

[20] W. F. Harrigan, Laboratory methods in Food Microbiology, Academic press Limited, London, 1998.

[21] Y. J. Arocho, D. Bellmer, N. Maness, W. Mcglynn and P. RayasDuarte, Watermelon pomace composition and the effect of drying and storage on lycopene content and color, Journal of Food Quality, vol. 35 pp. 331-340, 2012.

[22] C. Liu, H. Zhang, Z. Dai, X. Liu, Y. Liu, X. Deng, F. Chen and $\mathrm{J}$. Xu, Volatile chemical and carotenoid profiles in watermelons (Citrullus vulgaris (Thunb) Schrad (Cucurbitaceae) with different flesh colors, Food Science and Biotechnology, vol. 21, pp. $531-541,2012$.

[23] R. Siener, Dietary Treatment of Metabolic Acidosis in Chronic Kidney Disease. Nutrients, vol. 10, pp. 512, 2018. doi:10.3390/nu10040512

[24] S. K. C. Chang, Protein analysis. In: Nielsen SS, Food analysis. 4ed. Springer, New York, USA. 2010, pp. 135

[25] O. A. Ekpete; O. S. Edori and E. P. Fubare. Proximate and Mineral composition of some Nigeria fruits. British Journal of applied science and Technology, vol. 3, no. 4, pp. $1451-1452$. 2013

[26] M. R. Marshall, Ash analysis. In: Nielsen SS, Food analysis. 4ed. Springer, New York, USA. 2010, pp. 105-106

[27] E. S. Tee, S. I. Young, S. K. Ho and S. S. Mizur. Determination of vitamin $\mathrm{C}$ in fresh fruits and vegetables using the dye-titration and microfluorometric methods. Pertanika, vol. 11, no. 1, pp. 39 $-44.1988$

[28] Food and Nutrition Board, Institute of Medicine (US) Panel on Dietary Antioxidants and Related Compounds. Dietary Reference Intakes for Vitamin C, Vitamin E. Selenium, and Carotenoids. Washington (DC): National Academies Press (US); 2000. Food and Nutrition Board. https://www.ncbi,nim,nih.gov Access date 25 April 2020.

[29] A. W. Saul 2020 Vitaminc C protects against coronavirus OMNS January 26, 2020 Orthomolecular Medicine News Service. link http://orthomolecular.org/subscribe.html and OMNS archive link http://orthomolecular.org/resources/omns/index.shtml

[30] B. Ngo, J. M. V. Riper, L. C. Cantley, J. Yun, Targeting cancer vulnerabilities with high-dose vitamin C, Nature Reviews Cancer, vol. 19, no. 5, pp. 271-282, 2019.

[31] D. S. Bachoon and W. A. Dustman, "Exercise 8: Selective and differential media for isolation" In: M. Strange (ed), Microbiological laboratory manual. Mason OH. 2008

[32] C. Anderson, Great adventures in the microbiology laboratory, Pearson, pp.175-176, 2013. ISBN 978-1-269-39068-2

[33] W. F. Frazier and D. C. Westhoff, Food Microbiology $4^{\text {th }}$ ed, Tata McGraw-Hill, New Delhi, pp.21, 2005.

[34] S. A. Alsohaili and B. M. Bani-Hasan, Morphological and Molecular Identification of Fungi Isolated from Different Environmental Sources in the Northern Eastern Desert of Jordan, Jordan Journal of Biological Sciences, vol.11, no. 3, pp 329-337, July 2018 .

[35] Centre for Food Safety. Microbiological Guidelines for Food (For ready-to-eat food in general and specific food items), Centre for Food Safety and Food and Environmental Hygiene Department. 2014. Queensway, Hong Kong

[36] World Health Organization 2006. Five keys to safer food manual, Department of food safety, zoonoses and foodborne diseases, France. 2006. ISBN 9241594632.

[37] A. Adu - Gyamfi and J. Nketsia - Tabin. Microbiological studies of macaroni and Vegetable salad in Waakye, a local street food. Ghana Journal of Science, vol. 47, pp. 3-9, 2007.

[38] B. C. Adebayo - Tayo, N. N. Odu, N. J. P. N. Igiwiloh, I. O. Okonkwo, Microbiological and physiochemical level of fresh fish (Arius hendelotic) for different market in Akwa Ibom State, Nigeria. New York Science Journal, vol. 5, pp. 46-52, 2012.

[39] W. E. Adamoleccun and B, Adamokun, Bacteria associated with food processing, Nigeria Medical Practice, vol. 24, pp. 43 - 45, 1992

[40] M.O. Moss 2008. Fungi, quality and safety issues in fresh fruits and vegetables. Journal of Applied Microbiology, 104 (2008) 1239-1243

[41] M. O. Ofor, V. C. Okorie, I. I. Ibeawuchi, G. O. Ihejirika, O. P. Obilo and S. A. Dialoke. Microbial Contaminants in Fresh 
Tomato Wash Water and Food Safety Considerations in SouthEastern Nigeria. Life Science Journal, vol. 1, pp. 80-82, 2009.

[42] E. Amusan, C. K. Oramadiki, A. O. Abraham - Olukayode and O. A. Adejoriwo, Bacterial quality of street vended smoked Blue Whiting (Micromesistus poutasou). Internet Journal of Food Safely, vol. 12:122 -126, 2010.

[43] N. K. Sinha, J. S. Sidhu, J'. Barta, J. S. B. Wu and M. P. Cano. Handbook of Fruits and Fruit Processing. $2^{\text {nd }}$ ed. Oxford, UK John Wiley \& Sons, Ltd. 2012, pp 53. ISBN 978-0-8138-0894-9

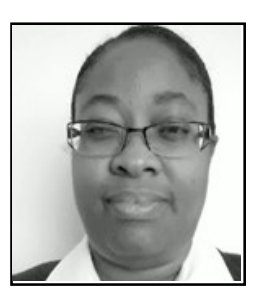

Patience C. Obinna-Echem, is a Lecturer in the Department of Food Science and Technology in the Faculty of Agriculture, Rivers State University, Port Harcourt, Nigeria. She obtained a Bachelor of Science degree in Food Science and Technology from Rivers State University of Science and Technology (now Rivers State University) Port Harcourt, Rivers State, Nigeria. She has a Master of Science degree in Food Quality and Safety Management and a Doctor of Philosophy Degree from University of Plymouth (now Plymouth University), United Kingdom.

Her $\mathrm{PhD}$ research work was based on the development of a probiotic functional food from a fermented maize food. She holds other relevant professional qualifications, some of which include: Level 2 Award in Food Safety in Catering, from Chartered Institute of Environmental Health, United Kingdom and Certificate of Professional Development, Learning and Teaching for General Teaching Associates. University of Plymouth, United Kingdom.

Her engagement in the Rivers State University, was from the position of Graduate assistance to Lecturer II, to Lecturer I and now a Senior Lecturer, where she takes courses in Food microbiology, Fermentation technology, Food quality, Food Safety, amongst others, at the undergraduate and post graduate levels. Her other relevant professional experiences are Technical Trainee in Quality Control Department in, Rivers Vegetable Oil Company Ltd (RIVOC), Educational Officer II in Federal Ministry of Education, Nigeria, and a Demonstrator in Food Microbiology at the Plymouth University UK.

Dr Obinna-Echem, has attended several local and international conferences and workshops, and authored several publications in different referred international journals including a book section. She is a member of the following professional bodies: Institute of Food Science and Technology (IFST) UK; Nigerian Institute of Food Science and Technology (NIFST); Society of Applied Microbiology (SfAM) and American Society for Microbiology (ASM). 